\title{
KONSTRUKSI PEMATANG TAMBAK TANAH GAMBUT UNTUK PENDEDERAN BENIH UDANG WINDU (Penaeus monodon) DAN NENER IKAN BANDENG (Cbanos chanos)
}

\author{
Akhmad Mustafa ${ }^{*}$, Adi Hanafi ${ }^{*}$ ) dan Brata Pantjara ${ }^{*}$ )
}

\begin{abstract}
ABSTRAK
Tambak tanah gambut memiliki tingkat porositas sangat tinggi. Oleh karena itu, dilakukan penelitian berbagai bahan penahan kebocoran pematang dilanjutkan dengan pendederan benih udang windu dan nener ikan bandeng untuk mengetahui konstruksi yang dapat menurunkan porositas pematang serta mengetahui pertumbuhan dan kelangsungan hidup udang windu dan ikan bandeng yang didederkan. Perlakuan yang diteliti adalah perbedaan bahan penahan kebocoran yaitu: pematang yang dilapisi tanah liat, dilapisi anyaman bambu dilabur ter, dilapisi plastik, dan tanpa bahan penahan kebocoran. Masing-masing perlakuan diulang dua kali dan disusun berdasarkan rancangan acak lengkap. Hewan uji, benih udang windu dan nener ikan bandeng, masingmasing ditempatkan dalam hapa dengan padat penebaran berturut-turut 500 dan 200 ekor $/ \mathrm{m}^{2}$ yang didederkan selama 20 hari.
\end{abstract}

Hasil penelitian menunjukkan bahwa pematang yang diberi penahan kebocoran dapat mengurangi penurunan air sekitar $8 \%$ dibandingkan dengan pematang yang tidak diberi penahan kebocoran setelah 48 jam dengan ketinggian awal air $50 \mathrm{~cm}$. Tambak tanah gambut yang baru dibangun dapat digunakan untuk pendederan udang windu dan ikan bandeng dengan memberikan kelangsungan hidup berturut-turut 82 dan $91 \%$ selama 20 hari.

\section{ABSTRACT: Dike Constructions of Peat Soil Pond for Rearing Tiger Prawn (Penceus monodon) and millfish (Cbanos cbanos) fries, by: Akbmad Mustafa, Adi Hanafi, and Brata Pantjara.}

Several covering materials were used in this experiment to decrease the water leaking through the dikes of peat soil ponds which is very high in porosity. To cover the dikes four different treatments were applied, namely the use of clay soil, bamboo net with asphalt coating, thick plastic sheet and one without any treatment. Each treatment was replicated twice and arranged in a completely randomised design.

The results showed that the material used could decrease the water leaking up to $8 \%$ after 48 hours with initial water height of $50 \mathrm{~cm}$. The newly constructed peat soil ponds were then used to rear the fingerlings of tiger prawn and milkfish in hapa for 20 days. Stocking densities were $500 \mathrm{ind} . / \mathrm{m}^{2}$ for tiger prawn and $200 \mathrm{ind} . / \mathrm{m}^{2}$ for milkfish. It was showed that the peat soil ponds were suitable to rearing fries of tiger prawn and milkfish giving survival rates of 82 and $91 \%$ within 20 days, respectively.

KEYWORDS: Dike constructions, peat soil, Penaeus monodon, Chanos chanos

\section{PENDAHULUAN}

Luas tanah gambut di Indonesia mencapai 10,9 juta ha (Widjaja-Adhi 1986). Tanah gambut adalah tanah dengan kandungan C-organik minimal $12 \%$

7) Peneliti pada Balai Penelitian Perikanan Pantai, Maros 
apabila fraksi liatnya $0 \%$ dan minimal $18 \%$ apabila fraksi liatnya lebih dari $60 \%$, di samping itu ketebalan gambutnya lebih dari $40 \mathrm{~cm}$ apabila berat isinya lebih besar dari $0,1 \mathrm{~g} / \mathrm{cm}^{3}$ atau lebih dari $60 \mathrm{~cm}$ apabila berat isinya lebih kecil dari $0,1 \mathrm{~g} / \mathrm{cm}^{3}$ (Widjaja-Adhi 1986; Widjaja-Adhi et al., 1992). Tanah gambut menurut Polak (1952) dalam Hakim et al. (1986) adalah tanah dengan ketebalan gambut $100 \mathrm{~cm}$ atau lebih dan apabila sudah diusahakan sebagai tanah pertanian tebal gambutnya $50 \mathrm{~cm}$ atau lebih.

Berdasarkan karakteristik tanah gambut, maka dijumpai berbagai kendala dalam pemanfaatannya untuk budidaya tambak, di antaranya dalam hal konstruksi tambak. Tanah gambut sangat rawan bagi konstruksi pematang, karena daya penyangga yang rendah dan persentase penyusutan yang tinggi, mudah longsor, dan tingkat porositasnya yang sangat tinggi. Kekurang-telitian dalam konstruksi tambak merupakan suatu penyebab utama rendahnya produktivitas tambak dan berakibat tidak berfungsinya tambak yang telah selesai dibangun.

Berbagai bahan penahan kebocoran pematang tambak telah dianjurkan untuk digunakan seperti tanah lempung atau liat (Poernomo 1989), plastik (Bose et al., 1991), serat kaca (fiberglass), ferrocement (dela Cruz 1983), beton atau baja (Wheaton 1977). Namun demikian, perlu pencarian bahan penahan kebocoran lain yang relatif mudah dan murah dalam mengurangi porositas pematang tambak, termasuk tambak tanah gambut.

Kualitas air tambak dapat dipengaruhi oleh desain, tata letak dan konstruksi tambak (Cholik dan Arifudin 1989). Oleh karena itu, dipandang perlu mengetahui pengaruh perbedaan konstruksi pematang tambak terhadap pertumbuhan dan kelangsungan hidup organisme akuatik di dalamnya, misalnya melalui pendederan benih udang windu (Penaeus monodon) dan nener ikan bandeng (Chanos chanos).

Berdasarkan pemikiran tersebut maka dilakukan penelitian dengan tujuan untuk mengetahui pertumbuhan dan kelangsungan hidup benih udang windu dan nener ikan bandeng yang didederkan dalam tambak tanah gambut dengan berbagai konstruksi pematang untuk menanggulangi kebocoran. Dari penelitian ini diharapkan diperoleh informasi pemanfaatan tambak tanah gambut yang baru dibangun untuk pendederan benih udang windu dan nener ikan bandeng dan juga mendapatkan konstruksi pematang tambak yang dapat mengurangi porositas tambak tanah gambut.

\section{BAHAN DAN METODE}

Penelitian konstruksi pematang tambak tanah gambut dilakukan pada hamparan tanah gambut seluas 1 ha yang terletak di Dusun Mallekana, Desa Pattiro Sompe, Kecamatan Sibulue, Kabupaten Bone. Pematang yang dibuat berukuran lebar atas $1,0 \mathrm{~m}$ dan tingginya $1,5 \mathrm{~m}$ dari calon pelataran tambak 
dengan kemiringan pematang $45^{\circ}$ (horizontal:vertikal $\left.=1: 1\right)$. Untuk mendapatkan pelataran tambak yang diinginkan maka dilakukan penggalian sampai 46 $\mathrm{cm}$ dari permukaan elevasi lahan yang ada. Luas petakan tambak yang dibangun adalah masing-masing $500 \mathrm{~m}^{2}\left(12,5 \times 40,0 \mathrm{~m}^{2}\right)$ sebanyak 8 petak. Sebagai perlakuan adalah perbedaan konstruksi pematang tambak, yaitu: pematang yang dilapisi tanah liat, pematang yang dilapisi anyaman bambu dilabur ter, pematang yang dilapisi plastik, dan pematang yang tidak diberi bahan penahan kebocoran (sebagai kontrol percobaan), masing-masing perlakuan diulang dua kali dan disusun berdasarkan rancangan acak lengkap.

Pematang yang diberi bahan penahan kebocoran, terlebih dahulu dibuatkan parit pada dasar calon pematang tambak sedalam $15 \mathrm{~cm}$ sesuai petunjuk Wheaton (1977), selanjutnya diisi dengan bahan penahan kebocoran yang akan dicoba. Tinggi bahan penahan kebocoran adalah $140 \mathrm{~cm}$ dari dasar parit, khusus untuk pematang yang diberi tanah liat lebarnya $25 \mathrm{~cm}$.

Setiap petakan tambak dilengkapi dengan pintu air yang berukuran panjang, lebar dan tinggi berturut-turut 2,0;0,8 dan 1,8 m. Air dimasukkan melalui pintu air secara gravitasi pada saat pasang tinggi atau dengan menggunakan pompa sepak yang dilewatkan melalui talang dari papan yang dilapisi plastik tebal.

Pengamatan penurunan tinggi air dilakukan pada hari pertama dan ke-60 sesudah tambak dibangun. Pada setiap pengamatan penurunan tinggi air, tambak terlebih dahulu diisi air setinggi $50 \mathrm{~cm}$ dan selanjutnya dicatat tinggi air dalam tambak setelah 24 dan 48 jam (selama pengamatan tidak terjadi hujan). Selain itu, juga dilakukan pengukuran bobot isi tanah dengan menggunakan ring sample pada bagian atas pematang dan kaki pematang bagian luar untuk semua petakan serta pada tanah dengan kondisi alami (belum terganggu). Di samping itu, juga dilakukan pengukuran penurunan pematang tambak pada saat empat bulan sesudah dibangun.

Sebagai hewan uji adalah benih udang windu pascalarva-15 yang diperoleh dari panti pembenih dan nener ikan bandeng alam asal perairan Kolaka, Sulawesi Tenggara. Bobot dan panjang rata-rata benih udang windu berturut-turut $0,002 \mathrm{~g}$ dan $11,6 \mathrm{~mm}$ dan untuk nener ikan bandeng adalah 0,01 $\mathrm{g}$ dan $16,3 \mathrm{~mm}$. Hewan uji ditempatkan dalam hapa berukuran $1 \times 1 \times 1 \mathrm{~m}^{3}$ yang dipasang $10 \mathrm{~cm}$ di atas pelataran tambak dan terendam air sekitar $50 \mathrm{~cm}$. Padat penebaran adalah 500 ekor/hapa untuk benih udang windu dan 200 ekor/hapa untuk nener ikan bandeng. Pada setiap petakan tambak ditempatkan masingmasing 1 unit hapa untuk setiap jenis hewan uji.

Pergantian air sebanyak 10-25\% dilakukan setiap 2-3 hari. Pakan yang diberikan kepada kedua jenis hewan uji tersebut adalah pakan udang windu ukuran remah (crumble) dengan komposisi seperti terlihat pada Table 1. Dosis pakan yang diberikan adalah $100 \%$ dari bobot total pada awal penelitian dan menurun menjadi $15 \%$ dari bobot total pada akhir penelitian. Pakan diberikan 
3 kali sehari yaitu pada pukul $08.00 ; 16.00$ dan 20.00. Pengukuran bobot hewan uji dilakukan setiap 5 hari, sekaligus dilakukan penyesuaian dosis pakan.

Table 1. Composition of feed used for rearing of tiger prawn and milkfish fries with different dike constructions of peat soil pond

\begin{tabular}{lc}
\hline \multicolumn{1}{c}{ Composition } & Percentage \\
\hline Protein & 38.71 \\
Lipid & 6.44 \\
Ash & 10.91 \\
Crude fiber & 1.40 \\
Water & 3.60 \\
Nitrogen-free extract & 38.94 \\
\hline \hline
\end{tabular}

Pengambilan contoh tanah secara komposit pada setiap petakan dilakukan pada awal dan akhir penelitian, sedangkan pengambilan contoh air dilakukan setiap lima hari untuk selanjutnya dianalisis di Laboratorium Kimia Balai Penelitian Perikanan Pantai, Maros. Selain itu, dilakukan pula pengukuran kualitas air langsung di lapangan setiap hari yang meliputi: salinitas, suhu, $\mathrm{pH}$, kecerahan, dan kedalaman air. Analisis bakteri dalam air dilakukan pada awal dan akhir penelitian. Isolasi dilakukan pada dua jenis agar dalam piring petri, yaitu TSA (Tryptic Soy Agar) sebagai media umum dan TCBSA (Thiosulphate Citrate Bile Sucrose Agar) sebagai media selektif. Jumlah koloni bakteri dihitung berdasarkan total viable count (Austin, 1987), sedangkan bakteri diidentifikasi berdasarkan modifikasi dari metode Cowan dan Steel (1974). Lama pendederan adalah 20 hari yang dilanjutkan dengan penghitungan laju kelangsungan hidup berdasarkan rumus Ricker (1975).

Data kelangsungan hidup, bobot, panjang, dan biomassa yang diperoleh dilakukan analisis sidik ragam dengan menggunakan program MSUSTAT. Peubah yang berbeda nyata diuji lanjut dengan uji Beda Nyata Terkecil (Petersen 1985). Sedangkan data lainnya dianalisis secara deskriptif.

\section{HASIL. DAN PEMBAHASAN}

\section{Konstruksi}

Penurunan tinggi air dalam tambak tanah gambut dengan konstruksi pematang yang berbeda terlihat pada Table 2. Adanya penurunan tinggi air ini diasumsikan hanya melalui pematang tambak saja (secara horizontal), seperti telah dilaporkan oleh Suhardjo (1994), bahwa di tanah gambut daya rembes air secara vertikal sangat lambat, sedangkan secara horizontal sangat cepat. 
Table 2. Water level decrease at different dike constructions for peat soil ponds at several observation periods

\begin{tabular}{lccc}
\hline \multirow{2}{*}{ Dike construction } & $\begin{array}{c}\text { Observation periods } \\
\text { (day after dike } \\
\text { construction) }\end{array}$ & $\begin{array}{c}\text { Water level decrease } \\
(\mathbf{c m})\end{array}$ \\
\cline { 3 - 5 } & 1 & $\mathbf{2 4}$ bours & $\mathbf{4 8}$ bours* \\
\hline Dike covered with clay soil & 60 & 7.5 & 11.5 \\
Dike covered with bamboo & 1 & 6.5 & 4.0 \\
net with asphalt coating & 60 & 2.0 & 9.5 \\
Dike covered with thick & 1 & 6.0 & 8.5 \\
plastic sheet & 60 & 2.0 & 3.5 \\
Dike without any covering & 1 & 8.0 & 13.0 \\
material & 60 & 5.0 & 8.5 \\
\hline
\end{tabular}

$*$ = Cummulative

Dari Table 2 terlihat bahwa pemberian berbagai bahan penahan kebocoran dapat mengurangi penurunan tinggi air jika dibandingkan dengan pernatang tambak tanpa bahan penahan kebocoran. Penggunaan bahan penahan kebocoran pada pematang tambak tanah gambut dapat mengurangi penurunan tinggi air sebesar $4 \mathrm{~cm}$ dari tinggi air $50 \mathrm{~cm}(8 \%)$ setelah 48 jam diisi air. Penurunan tinggi air terendah dijumpai pada pematang tambak yang diberi penahan kebocoran dari plastik. Hal ini sebagai akibat dari plastik yang tergolong sebagai bahan yang kedap air, sedangkan bahan lainnya masih dapat dilewati oleh air. Namun demikian, masih perlu pemantauan mengenai ketahanan dari setiap bahan yang digunakan untuk jangka waktu tertentu. Dikatakan oleh Poernomo (1989), tambak yang dibangun di kawasan hutan mangrove (termasuk tambak tanah gambut) tidak boleh mengabaikan pembuatan inti pematang dengan tanah lempung atau liat, kalau perlu tanah tersebut diangkut dari tempat lain. Selanjutnya Bose et al. (1991) menyatakan untuk mengurangi rembesan air pada pematang tambak dapat digunakan inti pematang, membuat pematang lebih kompak, dan pemasangan plastik secara vertikal dalam pematang.

Terlihat pula bahwa, laju penurunan tinggi air menurun sampai pada pengamatan 60 hari sesudah percobaan dimulai. Hal ini disebabkan adanya proses pemampatan tanah pematang tambak oleh bobot tanah itu sendiri atau karena adanya hujan. Seperti dikatakan oleh Driessen dan Soepraptohardjo (1974), pemampatan pada tanah gambut dapat meningkatkan daya dukung tanah, daya pegang tanah, dan menurunkan porositas tanah. Selanjutnya dikatakan oleh Kertonegoro dan Soekodarmodjo (1987 dalam Toro 1993), pemampatan menyebabkan fase cair dalam pori tanah bersinggungan secara fisik dengan fase padat. Hal ini sangat nyata terlihat pada konstruksi pematang 
tambak yang diberi tanah liat, di mana tanah liat ini cenderung mengisi rongga tanah gambut sehingga tingkat porositas tanah gambut dapat berkurang.

Pematang yang dilapisi plastik, sampai empat bulan sesudah dibangun belum dijumpai adanya kebocoran. Berdasarkan pengamatan terlihat bahwa pematang yang diberi plastik memiliki kelemahan karena antara plastik dengan tanah itu sendiri tidak saling melekat. Selain itu, plastik dapat bocor oleh sisa-sisa akar, batang atau tangkai kayu, terutama jika bahan tanah untuk pematang tambak masih banyak mempunyai sisa-sisa akar, batang, dan tangkai kayu. Diperoleh pula informasi dari seorang petambak di Kabupaten Bone (Sulawesi Selatan) bahwa, plastik dapat sobek jika tekanan air cukup besar karena konstruksi pematang yang kurang baik.

Pematang tambak yang dilapisi anyaman bambu walaupun telah dilabur ter ternyata pada anyaman bambu masih tetap ada bocoran sebelum dipasang di tengah pematang dan ternyata bocoran itu tertutupi oleh tanah yang dapat menyatu dengan anyaman bambu. Dengan demikian, pematang yang diberi anyaman bambu yang dilapisi ter cukup baik untuk menurunkan porositas pematang tambak tanah gambut.

Bobot isi tanah dapat digunakan untuk mengetahui tingkat porositas tanah. Bobot isi tanah pada pematang tambak tanah gambut berkisar 0,29 sampai 0,44 $\mathrm{g} / \mathrm{cm}^{3}$ (Table 3), sedangkan bobot isi tanah yang dijadikan bahan pematang rata-rata $0,54 \mathrm{~g} / \mathrm{cm}^{3}$, lebih rendah dari bobot isi tanah mineral. Menurut Sarief (1989) tanah mineral misalnya jenis tanah aluvial memiliki bobot isi tanah $1,02-1,42 \mathrm{~g} / \mathrm{cm}^{3}$. Menurunnya bobot isi tanah setelah dijadikan pematang tambak diduga disebabkan oleh adanya perlakuan fisik pada saat pengangkatan dan pengangkutan tanah yang dapat menyebabkan terbentuknya rongga atau pori setelah dijadikan pematang. Rongga ini akan semakin besar pada posisi antara balok tanah yang satu dengan yang lainnya apalagi pembuatan pematang dilakukan secara manual.

Table 3. Bulk density of soil of upper and lower parts of dike at different constructions after four montbs of construction

\begin{tabular}{lccc}
\hline \multicolumn{1}{c}{ Dike construction } & \multicolumn{3}{c}{ Bulk density $\left(\mathrm{g} / \mathrm{cm}^{3}\right)$} \\
\cline { 2 - 4 } & Upper part & Lower part & Average \\
\hline Dike covered with clay soil & 0.43 & 0.32 & 0.38 \\
$\begin{array}{l}\text { Dike covered with bamboo } \\
\text { net with asphalt coating }\end{array}$ & 0.40 & 0.29 & 0.35 \\
$\begin{array}{l}\text { Dike covered with thick } \\
\text { plastic sheet }\end{array}$ & 0.37 & 0.32 & 0.35 \\
$\begin{array}{l}\text { Dike without any covering } \\
\text { material }\end{array}$ & 0.44 & 0.30 & 0.37 \\
\hline \hline
\end{tabular}


Dari Table 3 terlihat bahwa, bobot isi tanah pada bagian atas pematang lebih tinggi dibandingkan dengan pada kaki pematang, hal ini dapat diakibatkan oleh perombakan bahan organik yang lebih intensif pada bagian atas pematang karena panas dan hujan sehingga hasil perombakan serasah dan atau bahan organik yang lebih halus dapat mengisi pori tanah. Terlihat pula adanya kecenderungan bobot isi tanah yang lebih tinggi pada pematang yang diberi tanah liat, karena tanah liat itu mengisi rongga atau pori tanah gambut sehingga lebih padat.

Hasil pengukuran penurunan tinggi pematang tambak menunjukkan bahwa terjadi penurunan permukaan tanah gambut sekitar $12-19 \mathrm{~cm}$ selama 4 bulan. Laju penurunan permukaan tanah pada pematang tambak ini ternyata lebih tinggi daripada penurunan permukaan tanah gambut asli yang hanya berkisar $0,4-9,1 \mathrm{~cm} / \mathrm{th}$ (Weir 1950 dalam Lopulisa 1993). Penurunan pematang tambak tanah gambut pada empat bulan pertama sesudah dibangun disebabkan oleh rongga yang terbentuk pada awal dibangun akan terisi oleh tanah dari bagian atas atau sampingnya sehingga terjadi penurunan permukaan tinggi pematang. Sedangkan pada tanah gambut asli proses penurunan secara alami sudah berjalan secara terus-menerus sehingga laju penurunannya menjadi kecil. Deposit organik bila dikeringkan akan mengalami penurunan permukaan karena hilangnya buoyant force dan pengompakan bahan organik oleh pengaruh bobotnya sendiri (Lopulisa 1993). Oksidasi biologis, erosi air/angin, dan pencucian bahan organik terlarut merupakan proses yang mendominasi penurunan permukaan tanah.

\section{Pendederan}

Hasil pendederan benih udang windu dan nener ikan bandeng pada konstruksi pematang tambak tanah gambut yang berbeda dapat dilihat pada Table 4. Hasil analisis sidik ragam menunjukkan bahwa perbedaan konstruksi pematang tambak tanah gambut berpengaruh tidak nyata $(P>0,05)$ terhadap bobot, panjang, kelangsungan hidup, dan biomassa benih udang windu maupun nener ikan bandeng. Kelangsungan hidup benih udang windu dan nener ikan bandeng yang diperoleh pada penelitian ini tergolong tinggi, masing-masing rata-rata $82 \%$ dan $91 \%$. Tjaronge et al. (1987) mendapatkan kelangsungan hidup $68 \%$ pada pendederan benih udang windu dengan sistem hapa dalam tambak tanah mineral pada padat penebaran $700 \mathrm{ekor} / \mathrm{m}^{2}$ yang diberi pelet selama 15 hari pendederan. Selanjutnya Kahar dan Amin (1988) mendapatkan kelangsungan hidup nener ikan bandeng sebesar $62 \%$ pada pendederan dengan sistem terkontrol pada padat penebaran sama dengan yang diaplikasikan pada percobaan ini $\left(200 \mathrm{ekor} / \mathrm{m}^{2}\right)$ setelah didederkan selama 30 hari.

Dari Table 4 terlihat bahwa bobot dan panjang rata-rata nener ikan bandeng berturut-turut $0,458 \mathrm{~g}$ dan $30,2 \mathrm{~mm}$, lebih baik dari temuan Kahar 
dan Amin (1988) yang mendapatkan bobot $0,313 \mathrm{~g}$ (dari bobot awal 0,052 $\mathrm{g}$ ) dan panjang 22,9 $\mathrm{mm}$ (dari panjang awal 12,6 $\mathrm{mm}$ ) pada pendederan nener ikan bandeng dengan sistem terkontrol pada padat penebaran $200 \mathrm{ekor} / \mathrm{m}^{2}$ selama 30 hari.

Table 4. Growth rate, survival rate, and biomass of tiger prawn and milkfish fries in a newly constructed peat soil pond within 20 days

\begin{tabular}{llcccc}
\hline \hline Dike construction & Commodity & $\begin{array}{c}\text { Final } \\
\text { weight } \\
(\mathbf{g})\end{array}$ & $\begin{array}{c}\text { Final } \\
\text { length } \\
(\mathbf{m m})\end{array}$ & $\begin{array}{c}\text { Survival Biomass } \\
\text { rate } \\
(\%)\end{array}$ & $(\mathrm{g})$ \\
\hline Dike covered with clay & Tiger prawn & 0.090 & 26.3 & 82 & 36.90 \\
soil & Milkfish & 0.400 & 27.8 & 92 & 73.60 \\
Dike covered with bamboo & Tiger prawn & 0.077 & 25.9 & 83 & 31.96 \\
net with asphalt coating & Milkfish & 0.460 & 30.0 & 88 & 80.96 \\
Dike covered with thick & Tiger prawn & 0.080 & 25.7 & 87 & 34.80 \\
plastic sheet & Milkfish & 0.440 & 29.8 & 96 & $\mathbf{8 4 . 4 8}$ \\
Dike without any covering & Tiger prawn & 0.064 & 24.6 & 76 & $\mathbf{2 4 . 3 2}$ \\
material & Milkfish & 0.530 & 33.3 & $\mathbf{8 8}$ & $\mathbf{9 3 . 2 8}$ \\
\hline \hline
\end{tabular}

Walaupun perbedaan konstruksi tidak memberikan pengaruh nyata, namun dari Table 4 terlihat bahwa bobot, panjang, kelangsungan hidup dan biomassa benih udang windu yang dipelihara pada tambak dengan konstruksi pematang tanpa bahan penahan kebocoran lebih rendah dibandingkan dengan perlakuan lain. Hal ini diduga karena tingkat penurunan tinggi air yang lebih besar pada pematang tambak tanpa perlakuan sehingga kedalaman air relatif lebih rendah yang menyebabkan suhu air relatif lebih tinggi (Table 5). Telah dilaporkan bahwa tanah gambut sangat cepat menjadi panas dan sangat lambat menghantar panas, mengakibatkan suhunya sangat bervariasi pada permukaan tanah (Suhardjo 1994) yang selanjutnya dapat mempengaruhi suhu air tambak.

Pertumbuhan terbaik dari nener ikan bandeng didapatkan pada tambak dengan pematang yang tidak diberi bahan penahan kebocoran dengan tinggi air lebih rendah dari tambak yang diberi bahan penahan kebocoran dan suhu airnya lebih tinggi dari tambak yang diberi bahan penahan kebocoran. Dilaporkan bahwa ikan bandeng tergolong organisme akuatik yang relatif toleran pada berbagai kondisi lingkungan perairan termasuk suhu yang tinggi. Telah diketahui bahwa suhu sangat berpengaruh terhadap laju proses metabolisme (termasuk pertumbuhan) dan kelangsungan hidup ikan maupun organisme lainnya dalam tambak, sehingga diduga suhu air dalam tambak tanpa bahan penahan kebocoran masih berpengaruh baik terhadap pertumbuhan nener ikan bandeng. 


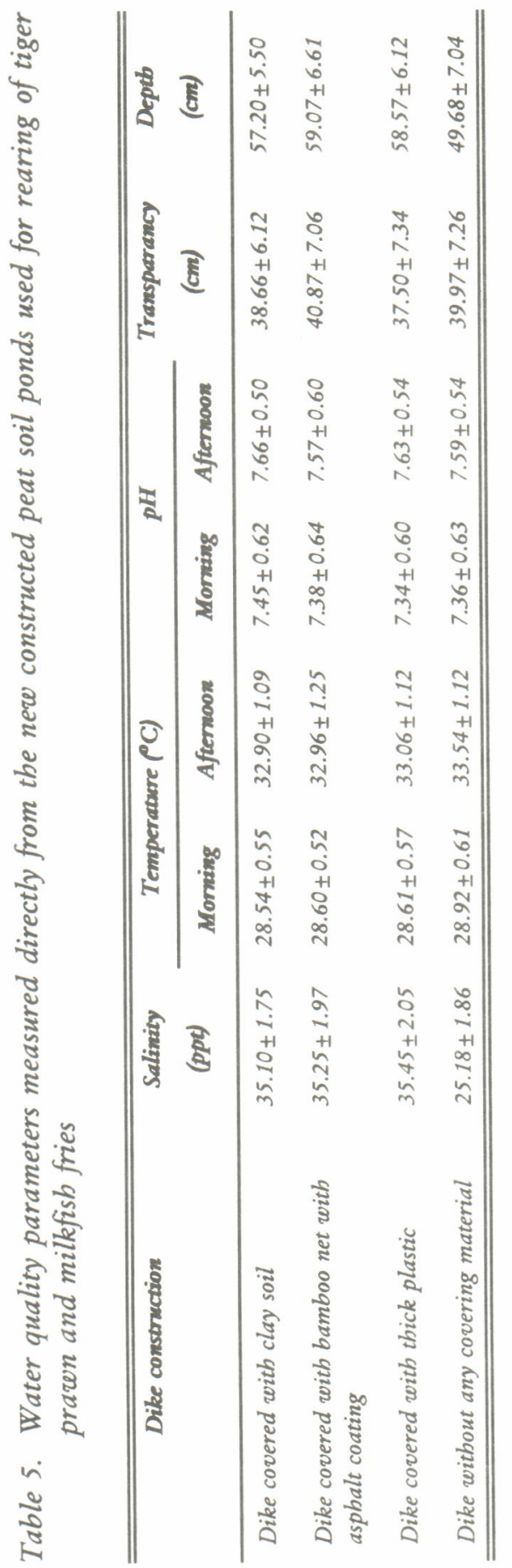


Peubah kualitas air lainnya misalnya salinitas, $\mathrm{pH}$, kecerahan, total padatan tersuspensi, total bahan organik, $\mathrm{NO}_{2}-\mathrm{N}, \mathrm{NO}_{3}-\mathrm{N}, \mathrm{NH}_{4}-\mathrm{N}, \mathrm{PO}_{4}-\mathrm{P}$, dan $\mathrm{Fe}$ (Table 5 dan 6) relatif sama di antara semua perlakuan dan dapat mendukung pertumbuhan dan kehidupan udang windu maupun ikan bandeng. Dalam hal ini terlihat bahwa perbedaan konstruksi pematang tambak yang diteliti tidak mempengaruhi kualitas air.

Table 6. Water quality variables at the new constructed peat soil ponds used for rearing of tiger prawn dan milkfish fries

\begin{tabular}{|c|c|c|c|c|}
\hline Variable & \multicolumn{4}{|c|}{ Treatment } \\
\hline & $\boldsymbol{A}$ & $\boldsymbol{B}$ & $C$ & $D$ \\
\hline$(p p m)$ & $1,166 \pm 350$ & $1,093 \pm 294$ & $1,027 \pm 339$ & $1,313 \pm 643$ \\
\hline TOM (ppm) & $6.71 \pm 3.75$ & $6.33 \pm 1.83$ & $5.64 \pm 0.47$ & $6.16 \pm 1.88$ \\
\hline$N O 2-N(p p m)$ & $0.0110 \pm 0.0054$ & $0.0149 \pm 0.0183$ & $0.0095 \pm 0.0050$ & $0.0092 \pm 0.0055$ \\
\hline NO3-N (ppm) & $0.0128 \pm 0.0160$ & $0.0098 \pm 0.0169$ & $0.0120 \pm 0.0105$ & $0.0059 \pm 0.0096$ \\
\hline$N H 4-N(p p m)$ & $0.0627 \pm 0.0459$ & $0.0665 \pm 0.0231$ & $0.0789 \pm 0.0183$ & $0.0861 \pm 0.0101$ \\
\hline PO4-P (ppm) & $0.0339 \pm 0.0004$ & $0.0339 \pm 0.0004$ & $0.0306 \pm 0.0107$ & $0.0305 \pm 0.0107$ \\
\hline$(p p m)$ & $0.3622 \pm 0.1785$ & $0.2170 \pm 0.2549$ & $0.2466 \pm 0.2187$ & $0.3558 \pm 0.2581$ \\
\hline Note: $\begin{array}{l}\text { TSS } \\
\text { TOM } \\
\text { A } \\
\text { B } \\
\text { C } \\
D\end{array}$ & $\begin{array}{l}=\text { Total suspended sol } \\
=\text { Total organic matte } \\
=\text { Dike covered with } \\
=\text { Dike covered with } \\
=\text { Dike covered with } \\
=\text { Dike without any }\end{array}$ & $\begin{array}{l}\text { tid } \\
\text { ter } \\
\text { clay soil } \\
\text { bamboo net with asp } \\
\text { thick plastic } \\
\text { covering material }\end{array}$ & phalt coating & \\
\hline
\end{tabular}

\section{Kondisi Mikroba}

Pada awal penelitian, bakteri yang didapatkan dalam contoh air ada 8 jenis (Table 7) dan menurun menjadi 6 jenis pada akhir penelitian (Table 8). Jenis bakteri yang didapatkan termasuk yang bersifat patogen terhadap udang windu di tambak. Bakteri gram negatif yang dapat menyebabkan penyakit pada udang windu adalah dari genera Vibrio, Aeromonas, Pseudomonas, dan Leucotbrix (Anderson et al., 1988). Sedangkan beberapa spesies dari kelompok bakteri Enterobacteriaceae dilaporkan tergolong patogen terhadap organisme perairan di daerah tropis dan subtropis (Sanders dan Fryer 1988). Penyebab kematian masal udang windu di tambak Kabupaten Pinrang (Sulawesi Selatan) adalah dari kelompok Enterobacteriaceae (Atmomarsono et al., 1993). 


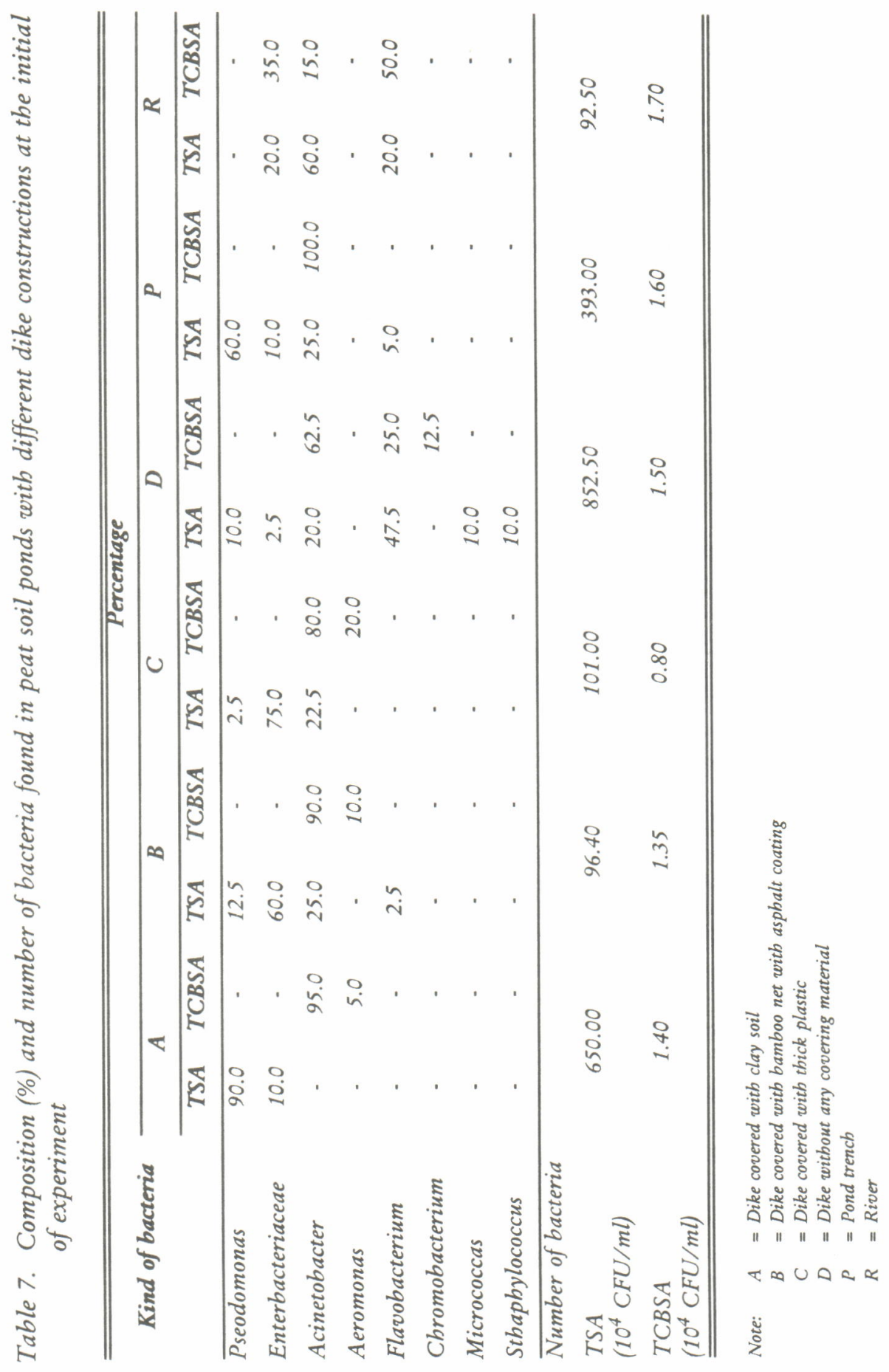




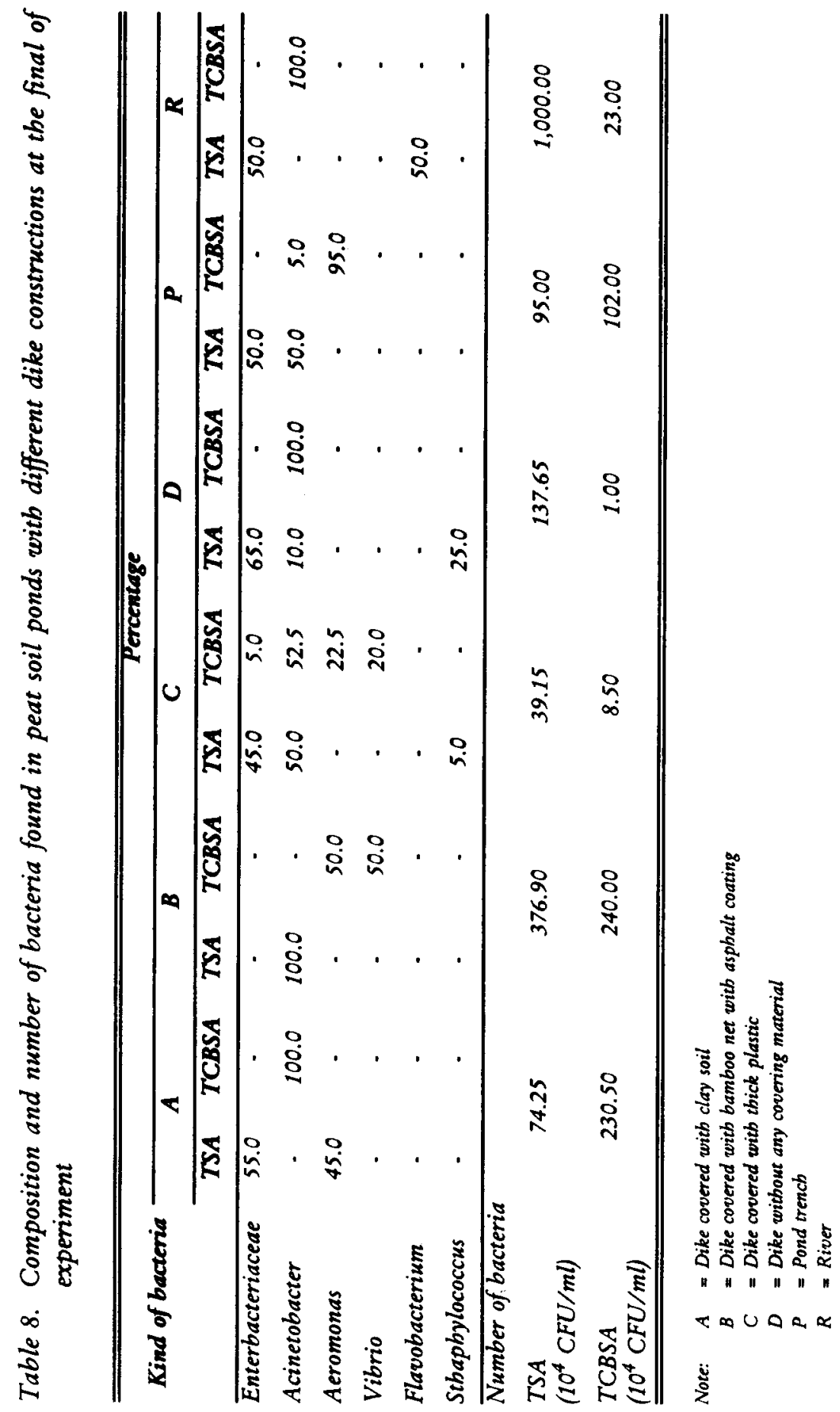


Jumlah bakteri yang didapatkan dalam contoh air berkisar $96,40-852,50 \times 10^{4}$ CFU $/ \mathrm{ml}$ pada media TSA dan $0,80-1,50 \times 10^{2} \mathrm{CFU} / \mathrm{ml}$ pada media TCBSA di awal penelitian dan $39,15-137,65 \times 10^{4} \mathrm{CFU} / \mathrm{ml}$ pada media TSA dan 1,00 $240,00 \times 10^{4} \mathrm{CFU} / \mathrm{ml}$ pada media TCBSA di akhir penelitian. Jumlah bakteri dalam contoh air di awal penelitian belum membahayakan kehidupan udang windu di tambak, tetapi dengan adanya peningkatan jumlah bakteri dalam air di akhir penelitian maka keadaan tersebut dapat digolongkan membahayakan kehidupan organisme, sebab kandungan bakteri di atas $10^{3} \mathrm{CFU} / \mathrm{ml}$ pada media TCBSA sudah dianggap membahayakan kehidupan udang windu di tambak (Atmomarsono et al., 1993). Adanya bakteri tersebut diduga sebagai penyebab adanya kematian dari benih udang windu dan nener ikan bandeng yang didederkan.

Tingginya kandungan bahan organik pada tambak tanah gambut, diduga merupakan media yang baik bagi perkembang biakan bakteri. Di samping itu, tingginya jumlah bakteri dapat pula disebabkan oleh sumber air (sungai) yang digunakan untuk tambak seperti terlihat pada Table 7 dan Table 8, di mana

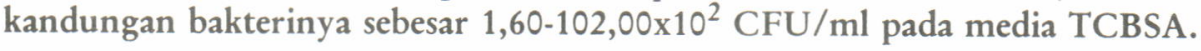

\section{Kualitas Tanah}

Kualitas tanah relatif sama pada setiap perlakuan. Akan tetapi di akhir penelitian terlihat adanya peningkatan semua peubah kualitas tanah walaupun relatif kecil (Table 9). Nilai $\mathrm{pH}\left(\mathrm{H}_{2} \mathrm{O}\right)$ tanah meningkat dari rata-rata 4,41 menjadi 4,62 sedangkan redox, bahan organik, $\mathrm{Fe}, \mathrm{Al}$ dan $\mathrm{SO}_{4}$ menurun berturut-turut dari rata-rata $239 \mathrm{mV}, 13,05 \%, 16,918 \mathrm{ppm}, 5,899 \mathrm{ppm}$ dan $12,705 \mathrm{ppm}$ menjadi $221 \mathrm{mV}, 12,99 \%, 16,096 \mathrm{ppm}, 4,596 \mathrm{ppm}$, dan 9,657 ppm. Hal ini diduga karena adanya pergantian air yang mencapai $10-25 \%$ dari volume total setiap 2-3 hari yang membuang bahan-bahan penyebab kemasaman tanah. Namun demikian, kualitas tanah secara umum kurang mendukung pertumbuhan dan kehidupan benih udang windu maupun nener ikan bandeng, tapi dengan pengelolaan air yang baik kualitas air secara umum dapat ditingkatkan sehingga mampu mendukung pertumbuhan dan kehidupan benih udang windu dan nener ikan bandeng.

Walaupun ada perbaikan kualitas tanah pada akhir penelitian, namun dari Table 9 terlihat bahwa $\mathrm{pH}$ tanah masih tergolong sangat masam $(\mathrm{pH}$ lebih kecil dari 4,5) dan masam ( $\mathrm{pH} 4,5-5,5)$, tanah dalam tahap reaksi reduksi dan kandungan bahan organik tergolong sangat tinggi. Selain itu, juga terkandung unsur atau senyawa penyebab kemasaman seperti $\mathrm{Fe}, \mathrm{Al}$, dan $\mathrm{SO}_{4}$ sedangkan kandungan unsur hara makro seperti $\mathrm{P}$ tergolong sangat rendah. 


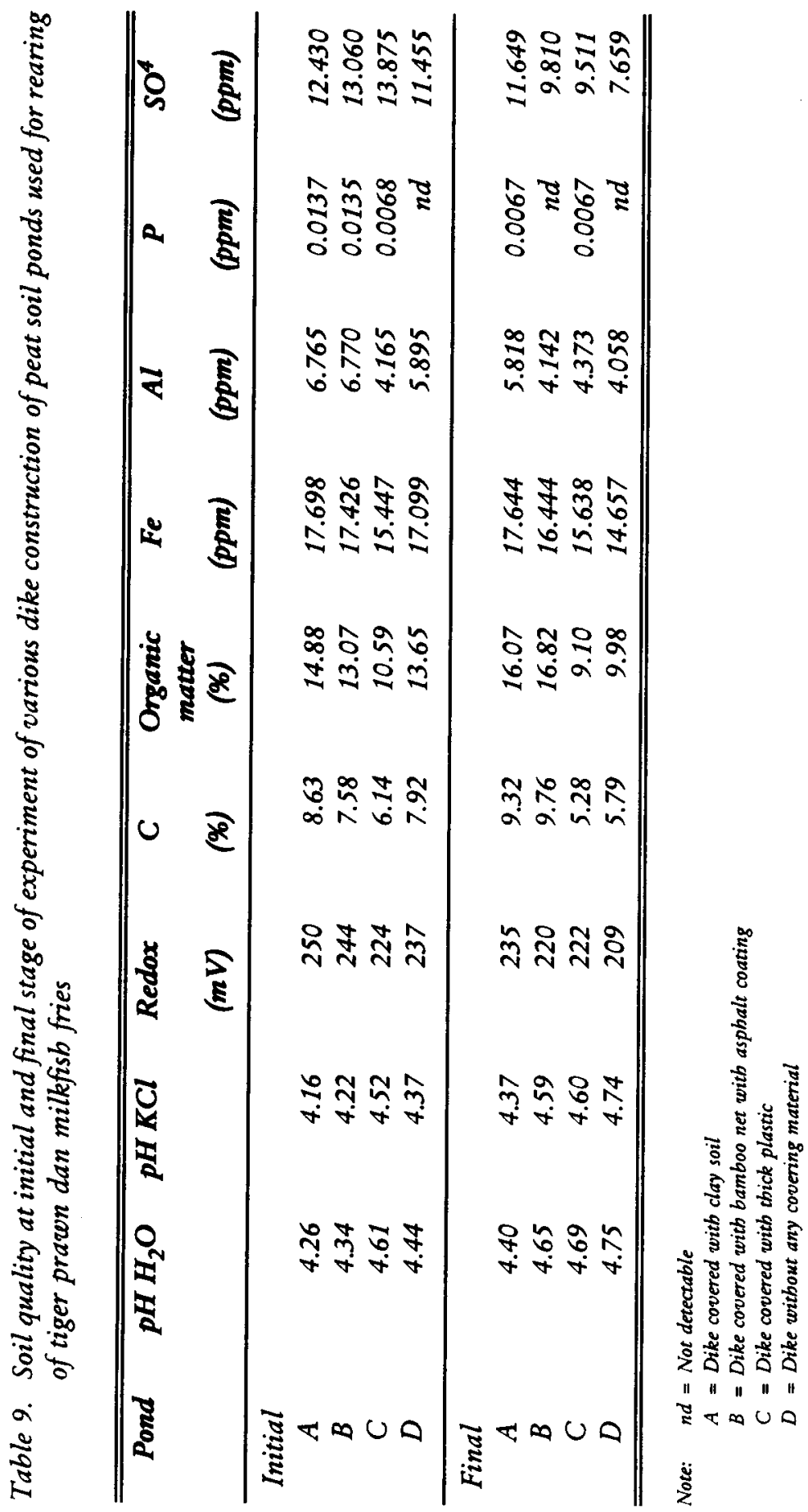




\section{KESIMPULAN DAN SARAN}

1. Penggunaan bahan penahan kebocoran pada pematang tambak tanah gambut yang diisi air setinggi $50 \mathrm{~cm}$ pada awalnya dapat mengurangi penurunan tinggi air sebesar $8 \%$ setelah 48 jam.

2. Tambak tanah gambut bukaan baru dengan berbagai macam konstruksi pematang yakni pematang yang dilapisi tanah liat, pematang yang dilapisi anyaman bambu dilabur ter, pematang yang dilapisi plastik, dan pematang tanpa bahan penahan kebocoran dapat digunakan untuk pendederan benih udang windu dan nener ikan bandeng dalam hapa dengan kelangsungan hidup berturut-turut rata-rata 82 dan $91 \%$ setelah didederkan selama 20 hari dengan sistem hapa.

3. Disarankan penelitian konstruksi pematang tambak tanah gambut dengan menggunakan bahan penahan kebocoran lainnya untuk budidaya udang windu termasuk analisis usahanya.

\section{UCAPAN TERIMA KASIH}

Diucapkan terima kasih kepada Sdr. Mappaseling, Penyuluh Pertanian Pratama pada Dinas Perikanan Daerah Tingkat II Kabupaten Bone (Sulawesi Selatan) atas bantuannya selama penelitian berlangsung.

\section{DAFTAR PUSTAKA}

Anderson I.G., M.N.Shamsuddin, M.Shariff, and G.Nash. 1988. Bacterial septicemia in juvenile tiger prawn, Penaeus monodon, cultured in Malaysian brackishwater ponds. Asian Fisheries Science 2:93-108.

Atmomarsono M., M.I.Madeali, Muliani, dan A.Tompo. 1993. Kasus penyakit udang windu di Kabupaten Pinrang. hal. 35-40. Dalam A.Hanafi, M.Atmomarsono, dan S.Ismawati (eds.), Prosiding Seminar Hasil Penelitian Perikanan Budidaya Pantai. Balai Penelitian Perikanan Budidaya Pantai, Maros.

Austin, B. 1987. Marine microbiology. Cambridge Univ. Press, Cambridge. $222 \mathrm{pp}$.

Bose A.N., S.N.Ghosh, C.T.Yang, and A.Mitra. 1991. Coastal aquaculture engineering. Oxford \& IBH Publishing Co. Pvt. Ltd., New Delhi. 365 pp.

Cholik F. dan R.Arifudin. 1989. Disain, tataletak dan konstruksi tambak udang. Pusat Penelitian dan Pengembangan Perikanan, Jakarta. 32 hal.

Cowan S.T. and K.J.Steel. 1974. Manual for identification of medical bacteria. Second Edition. Cambridge University Press, Cambridge. 238 pp. 
dela Cruz C.R. 1983. Fishpond engineering: A technical manual for small-and medium-scale coastal fish farm in Southeast Asia. South China Sea Fisheries Development and Coordinating Programme, Manila, Philippines. 180 pp.

Driessen P.M. and M.Soepraptohardjo. 1974. Soil for agriculture expansion in Indonesia. ATA 106 Bull. 1 Soil Res. Inst., Bogor:2-59.

Hakim N., M.Y.Nyakpa, A.M.Lubis, S.G.Nugroho, M.A.Diha, Go Ban Hong, dan H.H.Bailey. 1986. Dasar-dasar ilmu tanah. Penerbit Universitas Lampung, Bandarlampung. 488 hal.

Kahar dan M.Amin. 1988. Pengaruh berbagai padat penebaran terhadap pertumbuhan dan tingkat kematian nener dengan sistem terkontrol. J. Penel. Budidaya Pantai 4(2):22-26.

Lopulisa C. 1993. Klasifikasi gambut di Indonesia menurut US Soil Taxonomy dalam upaya meningkatkan pemahaman tentang sifat dan potensinya. Hal. 94-103. Dalam T.Sugeng, B.Setiadi, B.Nurachman, D.Mulyono, E.Nursahid, dan Kasiran (eds.), Prosiding Seminar Nasional Gambut II. Himpunan Gambut Indonesia dan Badan Pengkajian dan Penerapan Teknologi, Jakarta.

Petersen R.G. 1985. Design and analysis of experiments. Marcel Dekker, Inc., New York and Basel. 429 pp.

Poernomo A. 1989. Faktor lingkungan dominan pada budidaya udang intensif. Hal. 66-120. Dalam A. Bittner (ed.), Budidaya air. Yayasan Obor Indonesia, Jakarta.

Ricker W.E., 1975. Computation and interpretation of biological statistics of fish population. Bull. Fish. Res. Board Can. 191:382 pp.

Sanders E. and J.L.Fryer. 1988. Bacteria of fish. p. 115- 142. In B. Austin (ed.), Methods in aquatic bacteriology. John Wiley \& Sons, Chichester, England.

Suhardjo H. 1994. Tanah gambut. Pusat Penelitian Tanah dan Agroklimat, Bogor. 2 hal.

Tjaronge M., M.Mangampa dan A.M.Pirzan 1987. Pemanfaatan kerang sebagai pakan udang windu (Penaeus monodon) di pentokolan sistem hapa. Jur. Pen. BP 3(1):16-21.

Toro M.B. 1993. Perkembangan akar tanaman jagung serta penyerapan hara N dan $\mathrm{K}$ pada tanah gambut yang dimampatkan. Hal.231-237. Dalam T.Sugeng, B.Setiadi, B.Nurachman, D.Mulyono, E.Nursahid, dan Kasiran (eds.), Prosiding Seminar Nasional Gambut II. Himpunan Gambut Indonesia dan Badan Pengkajian dan Penerapan Teknologi, Jakarta.

Widjaja-Adhi I P.G. 1986. Pengelolaan lahan rawa pasang surut dan lebak. Jurnal Litbang Pertanian V(1):1-9. 
Widjaja-Adhi I P.G., K.Nugroho, S.Didi Ardi dan S.Karama. 1992. Hal. 19-38. Dalam S.Partohardjono dan M.Syam (eds.), Pengembangan terpadu pertanian lahan rawa pasang surut dan lebak. Pusat Penelitian dan Pengembangan Tanaman Pangan, Bogor.

Wheaton F.W. 1977. Aquacultural engineering. John Wiley \& Sons, New York, Chichester, Brisbane, Toronto. 708 pp. 